\title{
COMMENTARY
}

\section{Topical honey: for bears, not for ICU catheters?}

\author{
Jean-François Timsit, ${ }^{1,2 *}$ \\ See related research by Kwakman et al., http://ccforum.com/content/16/5/R214
}

\begin{abstract}
Catheters are most often colonized and become infected via the skin and their external surfaces in the ICU. Therefore, topical antimicrobials, including medical honey, placed at the insertion site should decrease skin colonization and catheter infections. This commentary reviews the main studies on, and the possible reasons of, topical antimicrobial failure in ICUs compared to the reported efficacy of chlorhexidine-impregnated dressings.
\end{abstract}

Colonization of the catheter occurs by two main pathways: the extra-luminal route or the intra-luminal route. The cutaneous entry site is the predominant route of colonization for short-term central vein catheters $(<15$ to 20 days), especially in ICU patients, whereas the endoluminal route, resulting from hub contamination, predominates for long-term central vein catheters [1].

Cutaneous colonization at the insertion site has been repeatedly associated with catheter colonization [2] and infection $[3,4]$. Therefore, decreasing bacterial flora at the insertion site might be an effective way to prevent catheterrelated bloodstream infections (CR-BSIs) in the ICU.

The efficacy of chlorhexidine-impregnated dressings to decrease cutaneous flora and CR-BSI has already been proven in ICU patients [3,4]. The concentration of chlorhexidine achieved under the dressing is always greater than 1,000-fold the minimum inhibitory concentration (MIC) of most microorganisms responsible for CR-BSI. However, the over-use of chlorhexidine as the exclusive antiseptic solution for CR-BSI prevention may enhance resistance mechanisms of bacteria to chlorhexidine [5].

Alternative anti-infective products, able to decrease cutaneous colonization and catheter infection, are awaited. Among topical antimicrobial candidates, povidone

\footnotetext{
*Correspondence: jftimsit@chu-grenoble.fr

'University Grenoble 1, Medical Polyvalent ICU; Albert Michallon University

Hospital, 38000 Grenoble, Cedex 9, France
}

Full list of author information is available at the end of the article iodine, mupirocin and polysporin (polymyxin, bacitracin, and neomycin) have been studied [6]. Results of randomized controlled trials (RCTs) on the efficacy of triple antibiotic ointment (polymyxin, bacitracin, and neomycin) applied to catheter insertion sites are indeterminate for central venous catheters due to the low number of CRBSIs observed. In a double blind RCT performed in longterm hemodialysis (HD) patients, polysporin significantly decreased exit site infection (relative risk 0.25, 95\% confidence interval (CI) 0.19 to 0.31 ) and bacteremia (relative risk $0.25,95 \%$ CI 0.19 to 0.34) [7]. Increased catheter colonization by Stenotrophomonas maltophilia and Candida species associated with use of triple antibiotic ointment may limit further investigations in the ICU [2].

Again, while the efficacy of povidone iodine ointment in decreasing bacteremia and local infection has been shown [8] in HD patients with long-term catheters, results of randomized studies of prophylactic use of povidone iodine ointment applied to insertion sites of short-term catheters for the prevention of CR-BSI are inconclusive (relative risk 1.0, 95\% CI 0.1 to 7.1 [2]). However, given the results of small before-and-after studies, RCTs should be promoted to test povidone iodine ointment efficacy in ICU settings [9].

Application of mupirocin ointment to insertion sites for temporary HD catheters reduces the risk for CR-BSI with Staphylococcus aureus (relative risk 0.1, 95\% CI 0.0 to 0.7) [6]. However, the emergence of mupirocin-resistant organisms and interference with the polyurethane of the catheters limit its use.

Honey is known to possess antimicrobial properties. Activity is due to the approximately $80 \%$ sugar content, low $\mathrm{pH}$, free radical production and other floral or bee components. Antimicrobial properties vary according to the environment where honey is collected and microbial resistance has never been reported. On healthy volunteer skin, medical grade honey is effective at concentrations greater than $20 \%$ for antibiotic-susceptible and -resistant bacteria [10]. For CR-BSI prevention, honey was as effective as mupirocin in long-term HD patients [6]. In a recent issue of Critical Care, Kwakman and colleagues report results of a single-ICU open-label RCT testing the added effect of medical grade honey in decreasing 
cutaneous colonization and infection of central vein catheters [11]. They found that colonization at the last sampling was nearly identical between patients with and without honey.

As the authors pointed out, the absence of efficacy of honey might be due to dilution or inactivation of honey in the skin moistures of diaphoretic patients, or to dressing disruption. Indeed, we found that transparent dressing changes earlier than the planned date because of disruption or leakage occurs up to $66 \%$ of the time in ICUs [12] and may favor topical antimicrobial leakage. These mechanisms may, more generally, explain the disappointing results with topical antimicrobials in preventing catheter-related infections in the ICU.

\section{Conclusion}

Further studies may use concentrations of topical antimicrobials that exceed by far the concentration necessary to kill skin microorganisms. However, considering the pathophysiology of CR-BSI with short-term catheter use, the potential of topical antimicrobials in decreasing catheter-related infection needs to be further tested.

\section{Abbreviations}

$\mathrm{Cl}$, confidence interval; CR-BSI, catheter-related bloodstream infection; $\mathrm{HD}$, hemodialysis; RCT, randomized controlled trial.

\section{Competing interests}

JFT served as speaker in symposia for $3 \mathrm{M}$ and Ethicon and received research grants from Carefusion, $3 \mathrm{M}$ and Ethicon.

\section{Author details}

'University Grenoble 1, Medical Polyvalent ICU; Albert Michallon University Hospital, 38000 Grenoble, Cedex 9, France. ${ }^{2}$ University Grenoble 1, U 823, Research tem 11: Outcome of airway cancers and critically ill patients.

Published: 15 January 2013

References

1. Mermel LA: What is the predominant source of intravascular catheter infections? Clin Infectious Dis 2011, 52:211-212.

2. Maki DG, Band JD: A comparative study of polyantibiotic and iodophor ointments in prevention of vascular catheter-related infection. Am J Med 1981, 70:739-744.
3. Timsit JF, Schwebel C, Bouadma L, Geffroy A, Garrouste-Orgeas M, Pease S, Herault MC, Haouache H, Calvino-Gunther S, Gestin B, Armand-Lefevre L, Leflon V, Chaplain C, Benali A, Francais A, Adrie C, Zahar JR, Thuong M, Arrault X, Croize J, Lucet JC; Dressing Study Group: Chlorhexidine-impregnated sponges and less frequent dressing changes for prevention of catheterrelated infections in critically ill adults: a randomized controlled trial. JAMA 2009, 301:1231-1241.

4. Timsit JF, Mimoz O, Mourvillier B, Souweine B, Garrouste-Orgeas M, Alfandari S, Plantefeve G, Bronchard R, Troche G, Gauzit R, Antona M, Canet E, Bohe J Lepape A, Vesin A, Arrault X, Schwebel C, Adrie C, Zahar JR, Ruckly S, Tournegros C, Lucet JC: Randomized controlled trial of chlorhexidine dressing and highly adhesive dressing for preventing catheter-related infections in critically ill adults. Am J Respir Criti Care Med 2012, 186:1272-1278.

5. Hu Y, Coates AR: Enhancement by novel anti-methicillin-resistant Staphylococcus aureus compound HT61 of the activity of neomycin, gentamicin, mupirocin and chlorhexidine: in vitro and in vivo studies. J Antimicrob Chemother 2012 [Epub ahead of print].

6. McCann M, Moore ZE: Interventions for preventing infectious complications in haemodialysis patients with central venous catheters. Cochrane Database Syst Rev 2010:CD006894.

7. Lok CE, Stanley KE, Hux JE, Richardson R, Tobe SW, Conly J: Hemodialysis infection prevention with polysporin ointment. J Am Soc Nephrol 2003, 14:169-179.

8. Levin A, Mason AJ, Jindal KK, Fong IW, Goldstein MB: Prevention of hemodialysis subclavian vein catheter infections by topical povidoneiodine. Kidney Int 1991, 40:934-938.

9. Fukunaga A, Naritaka H, Fukaya R, Tabuse M, Nakamura T: Povidone-iodine ointment and gauze dressings associated with reduced catheter-related infection in seriously ill neurosurgical patients. Infection Control Hospital Epidemiol 2004, 25:696-698.

10. Kwakman PH, de Boer L, Ruyter-Spira CP, Creemers-Molenaar T, Helsper JP, Vandenbroucke-Grauls CM, Zaat SA, te Velde AA: Medical-grade honey enriched with antimicrobial peptides has enhanced activity against antibiotic-resistant pathogens. Eur J Clin Microbiol Infect Dis 2011 30:251-257.

11. Kwakman PH, Muller MC, Binnekade JM, van den Akker JP, de Borgie CA Schultz MJ, Zaat SA: Medical-grade honey does not reduce skin colonization at central venous catheter insertion sites of critically ill patients: a randomized controlled trial. Crit Care 2012, 16:R214.

12. Timsit JF, Bouadma L, Ruckly S, Schwebel C, Garrouste-Orgeas M, Bronchard R, Calvino-Gunther S, Laupland K, Adrie C, Thuong M, Herault MC, Pease S, Arrault $X$, Lucet JC: Dressing disruption is a major risk factor for catheterrelated infections. Crit Care Med 2012,40:1707-1714.

doi:10.1186/cc11900

Cite this article as: Timsit JF: Topical honey: for bears, not for ICU catheters? Critical Care 2013, 17:103. 